Review

\title{
Candidate genes and single-nucleotide gene variants associated with muscle and tendon injuries in cyclic sports athletes
}

\author{
Olga V. Balberova
}

Citation: Balberova O.V . Title. Personalized Psychiatry and Neurology 2021, 1 (1): 64-72

Chief Editor: Nikolay G. Neznanov, D Med Sci, Professor

Received: 12 Febuary 2021

Accepted: 17 April 2021

Published: 14 May 2021

Publisher's Note: V. M. Bekhterev NMRC PN stays neutral with regard to jurisdictional claims in published maps and institutional affiliations .

Copyright: $₫ 2021$ by the authors.
The Ural State University of Physical Culture, Chelyabinsk, Russian Federation; Niios@bk.ru Correspondence: olga-balberova@mail.ru; Tel.: +7-351-217-09-58, Balberova O.V.

\begin{abstract}
Sports injuries prevention is one of the key issues of the training process and reducing the risk of developing anxiety and depressive disorders in professional athletes. One of peculiarities of sports injuries is the loss of the ability to train in view of the tendon-ligamentous apparatus integrity, joints, muscles or bones violation. In cyclic sports, the most common are injuries to the ankle joint, injuries to muscles and tendons, and sprains. Injuries to ligaments and tendons are the result of multifactorial problems, including the discrepancy between training effects and the genetically determined capabilities of the athlete's body. Sports injuries consequences are determined by complex interactions between the athlete's genotype and environmental factors, in particular training influences. (1) Background: to review scientific articles on the problem of research on candidate genes and single-nucleotide variants (SNVs) of genes associated with muscle, tendon, and ligament injuries in cyclic sports athletes. (2) Methods: a search of articles for the period from 2008 to 2020 was conducted in the databases e-LIBRARY, SCOPUS, Web of Science, Google Scholar, Clinical keys, PubMed using the keywords: personalized medicine, genetics, candidate genes, single-nucleotide variant, polymorphism, muscle, tendon, injury, athlete. (3) Results: Studies have shown that muscle and tendon injuries in cyclical sports athletes are associated with SNV rs1800012, rs1107946 of the COL1A1 gene, SNV rs12722 of the COL5A1 gene, SNV rs679620 of the MMR3 gene, SNV rs2289360 of the ELN gene, SNV rs143383 of the GDF5 gene. The most studied polymorphisms are rs1800012, rs1107946 of the COL1A1 gene, rs12722 of the COL5A1 gene, and rs143383 of the GDF5 gene. The variable results of associative genetic studies and genome-wide studies are most likely due to the racial and ethnic heterogeneity of the samples and differences in the study design. (4) Conclusions: Identification of genetic markers associated with injuries and diseases of the musculoskeletal system, ligamentous apparatus, and the ability of tissue to regenerate can help sports doctors and coaches develop personalized strategies to prevent or reduce muscles, joints, and ligaments diseases in athletes. The translation of these research results into the training and treatment process is important for improving cyclic sports athletes' performance, reducing their professional maladaptation and anxiety and depressive disorders development risk.
\end{abstract}

Keywords: personalized medicine, genetics, candidate gene, single nucleotide variant, polymorphism, muscles, tendons, injury, athlete.

\section{Introduction}

All biological processes associated with high sports performance, such as muscles, joints and bones formation, energy processes in muscles, metabolism, blood and tissues oxygenation, are genetically determined. Variations in nucleotides' sequence in deoxyribonucleic acid (DNA), in particular single-nucleotide variants (SNV), create genetic advantages, contributing to achieving high results in sports. On the other hand, they can create genetic «barriers» that prevent sports careers and anxiety-depressive disorders development in professional athletes. Predictive genomic DNA profiling identifies SNV that may be associated with a predisposition to sports injuries. Predictive genomics is an effective tool for developing personalized training programs to optimize health status and 
achieve high performance of the athlete. A personalized approach use in clinical practice can help reduce the risks associated with an athlete's health, including such as inflammation and skeletal muscles, ligaments, and tendons injuries resulting from high physical loadings [16].

The aim is to review studies of candidate genes and their SNVs, associated with muscle, tendon, and ligament injuries in cyclic sports athletes.

\section{Materials and Methods}

The author searched for articles from 2008 to 2020 in the databases e-LIBRARY, SCOPUS, Web of Science, Google Scholar, Clinical keys, PubMed using the keywords: personalized medicine, genetics, candidate gene, single-nucleotide variant, polymorphism, muscle, tendon, injury, athlete, and analyzed the results of open observational associative genetic studies of case-control published in English and Russian.

\section{Results}

Physical performance and the injury risk are related to muscles, ligaments and tendons properties, which depend on athletes' individual genotypes. Skeletal muscle consists approximately of $75 \%$ water, $20 \%$ protein, $1-10 \%$ fat, and $1 \%$ glycogen. Ligaments consist of about $2 / 3$ water [1]. The components of the remaining third include collagen, proteoglycans, elastin, and other proteins and glycoproteins, such as actin, laminin, and integrins [11]. The central part of the ligament consists of a composition of elastin and collagen fibers. In the terminal region of ligaments, collagen fibrils orientation is longitudinal, and the elastin fibers end inside the ligament without any attachment to the bone [4, 14].

Kambouris M. et al. (2012) showed that the SNV of two genes encoding collagen (COL1A1 and COL5A1), as well as the MMP3 gene involved in wound healing in connective tissue, and the TNC gene encoding extracellular matrix protein, were associated with an increased risk of sports tendinopathy [16,18]. The presence of multiple genes alleles associated with sports injuries risk in the tendon-ligamentous apparatus, respectively, further increases the risk of injuries [24].

In recent years, a number of Russian and foreign laboratories have studied the genetic predisposition to sports injuries by determining the polymorphisms of candidate genes: COL1A1 (G1245T rs1800012), COL1A1 (G1997T, rs1107946), COL5A1 (C/T, rs12722), MMP3 (Lus45Glu, rs679620), GDF5 (A/G rs143383).

\section{COL1A1 gene}

The COL1A1 gene (Collagen Type I Alpha 1 Chain) is localized on chromosome 17q21/33, Figure 1. The gene encodes the pro-alpha1 chains of type I collagen, the triple helix of which includes two chains - alpha1 and one alpha2 chain. Type I is a fibrillating collagen found in most connective tissues, in bones, cornea, dermis, and tendons [33].

There are many studies that report an association of SNV in the COL1A1 gene with a predisposition to damage to muscles, tendons, and ligaments [10,28,31,32]. SNV in the COL1A1 gene can alter its expression and affect the properties of the type I collagen protein, which can subsequently increase the risk of sports injuries. Among the various SNVs of the COL1A1 gene, $+1245 \mathrm{G} / \mathrm{T}$ (rs1800012) is the most studied. This SNV, which lies within the first intron of the COL1A1 gene, affects the binding site of the transcription factor Sp1 [32].

Ficek K. et al. (2013) showed a statistically significant association of the G-T haplotype carrier (- 1997G/T rs1107946 and $+1245 \mathrm{G} / \mathrm{T}$ rs1800012) of the COL1A1 gene with a reduced risk of anterior cruciate ligament rupture in professional athletes. Thus, the haplotype under consideration when carrying two copies may be protective against the risk of cruciate ligament injuries. The homozygous TT genotype was not sufficiently 
representative in the group of athletes with anterior cruciate ligament injury and was not statistically significant [10].

In the study of Stepien-Slodkowska M. et al. (2017) on the example of male cyclic sports athletes (cross-country skiing), no statistically significant association was found between the carrier of the SNV rs1800012 and the risk of cruciate ligament rupture, both in the group of skiers and in the control group. The homozygous GG genotype was unrepresentative in the athletes' group compared to the control group. No statistically significant differences were found in the carrier of the studied genotypes or alleles for the carrier of SNV rs1107946 in the skiers and the control group. At the same time, the GG genotype was the most common, although its carrier did not differ statistically significantly in skiers with a cruciate ligament tear and without it [28].

A meta-analysis conducted by Wang C. et al. (2017), including studies published in PubMed, Web Of Science, and Cochrane Library, showed that the SNV rs1800012 of COL1A1 gene may be associated with a reduced risk of sports injuries to tendons or ligaments, especially cruciate ligament injuries, and that the rare homozygous TT genotype may play a protective role [31].

\section{COL5A1 gene}

The COL5A1 gene (Collagen Type V Alpha 2 Chain) is located on chromosome 2q32. 2 , Figure 2. The gene encodes the alpha chain of one of fibrillar collagens. Its molecules are trimmers, which can consist of one or more types of alpha chains. Type V collagen is found in tissues containing type I collagen and appears to regulate the assembly of heterotypic fibers consisting of both type I and type $\mathrm{V}$ collagen. This gene product is closely related to type XI collagen, and it is possible that the collagen chains of types $\mathrm{V}$ and XI form a single type of collagen with tissue-specific chain combinations [34].

Injuries to the tendon-ligamentous apparatus, especially in people involved in sports, are of serious concern among sports doctors. It has recently been shown that the gene encoding the $\alpha 1$-chain of type I collagen (COL1A1) is associated with an increased risk of cruciate ligament tears, and the COL5A1 gene encoding the $\alpha 1$-chain of type $\mathrm{V}$ collagen is associated with Achilles tendon injuries [21,24].

Raleigh S.M. et al. (2009) conducted a study to determine the association of two variants of polymorphisms (restriction fragment length polymorphism BstUI and DpnII [RFLPs]) in COL5A1 gene with an increased risk of anterior cruciate ligament ruptures. In addition, gender associations between these two SNVs in the COL5A1 gene and risk of anterior cruciate ligament ruptures were investigated. Among female athletes, statistically significant differences were found, indicating an association between the frequency of the BstUI RFLP genotype and anterior cruciate ligament rupture. The CC genotype in female athletes was significantly less common in the group of individuals with anterior cruciate ligament rupture compared to the control group (odds ratio $(\mathrm{OR})=6.6$ ). In male athletes, this association was not detected. There were no differences in DpnII RFLP genotypes distribution between the anterior cruciate ligament rupture group and the control one $[21,24]$.

September A.V. et al. (2009) investigated the association of SNV in the COL5A1 gene with Achilles tendinopathy in two populations of athletes (South African and Australian). All athletes were genotyped for BstUI (rs12722) and DpnII (rs13946) RFLP carriers, as well as SNV-markers rs10858286, rs3196378, rs11103544, rs4504708, and rs3128575. The results showed that BstUI RFLP $(p<0.001)$ and marker rs3196378 $(p=0.016)$ were associated with chronic Achilles tendinopathy in Australian athletes. Athletes with the homozygous CC genotype for BstUI RFLP, regardless of their population, had a significantly lower risk of developing tendinopathy compared to any other genotypes $(\mathrm{OR}=0.42)$. The $\mathrm{T}-\mathrm{C}$ haplotype (rs12722, rs3196378) was more common in the group of South African athletes with tendinopathy compared to all other haplotypes [26].

MMP3 gene 
The MP3 (Matrix Metallopeptidase) gene is located on chromosome 11q 22.2, Figure 4. The gene encodes an enzyme that destroys fibronectin, laminin, collagens III, IV, IX, and $\mathrm{X}$, as well as cartilage proteoglycans [35]. The MMP3 enzyme is a marker of the risk of injuries to the musculoskeletal system.

Gibbon A. et al. (2017) conducted a study aimed at identifying an association between the SNVs of MMP3 gene and soft tissue injuries. Three previously studied SNVs of MMP3 genes (rs679620, rs591058, and rs650108), in addition to the functional promoter variant (rs3025058), were genotyped in Australian athletes: a control group without tendinopathy; a comparable group - athletes with chronic Achilles tendinopathy. Similarly, the genotypes of athletes from South Africa with acute anterior cruciate ligament rupture and South African athletes from the control group were analyzed. Based on the high degree of coupling with the previously associated SNV rs679620 of the MMP3 gene, it was concluded that rs3025058 was associated with an increased risk of Achilles tendinopathy in the South African group (OR=2.88). The haplotype 6A-GCG constructed from the studied SNVs was statistically significantly associated with a reduced risk of Achilles tendinopathy in the Australian group [12].

Raleigh S.M. et al. (2009) investigated the association between Achilles tendinopathy and SNV of the MMP3 and COL5A1 genes. The authors wanted to find out whether these SNVs are sports injuries predictors of the Achilles tendon in the European population. Statistically significant associations between the homozygous genotype GG rs679620 (OR = 2.5), the genotype CC rs591058 (OR = 2.3) and the genotype AA rs650108 (OR = 4.9) and the risk of Achilles tendinopathy were found as SNV-markers. The A-T-G haplotype (rs679620, rs591058, and rs650108) was underrepresented in the tendinopathy group compared to the control one $(41 \%$ vs. $53 \%, \mathrm{p}=0.038)$. Finally, the G-allele rs679620 and the Tallele rs12722 of the COL5A1 gene were genetic predictors of sports injuries in European athletes. No associations were found between any of the studied SNV markers of the MMP3 gene and Achilles tendon rupture [24].

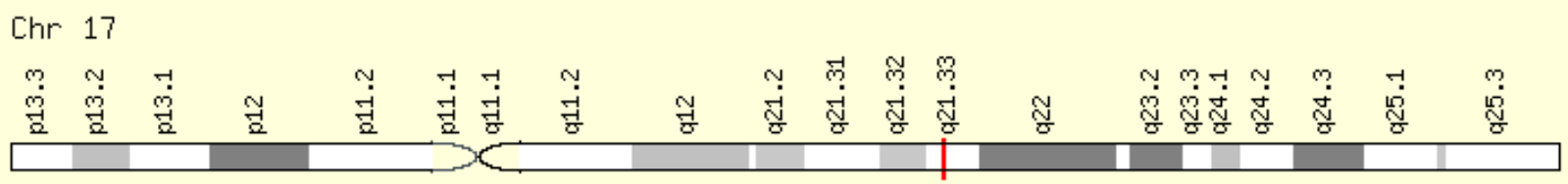

Figure 1. COL1A1 gene localization on chromosome 17q21.33 [33]

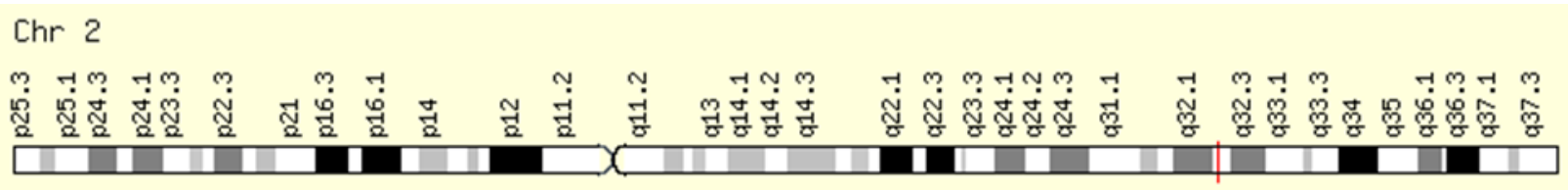

Figure 2. COL5A1 gene localization on chromosome 2q32.2 [34]

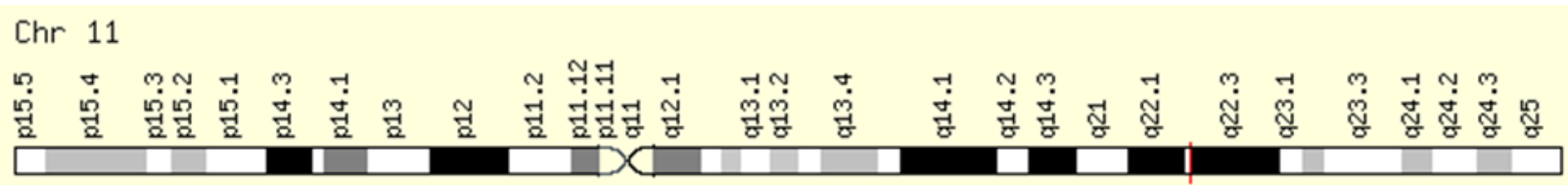

Figure 3. $M M P 3$ gene localization on chromosome 11q22.2 [35] 


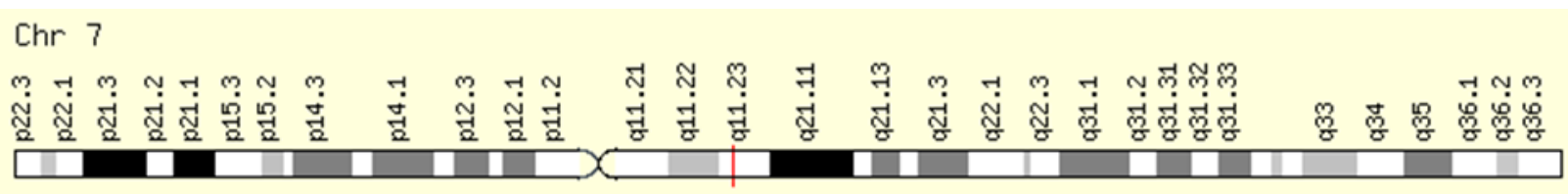

Figure 4. ELN gene localization on chromosome 7q11.23 [36]

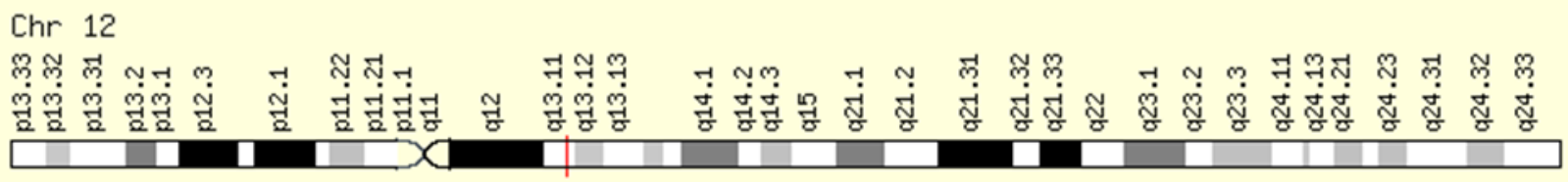

Figure 5. VDR gene localization on chromosome 12q13.11 [37].

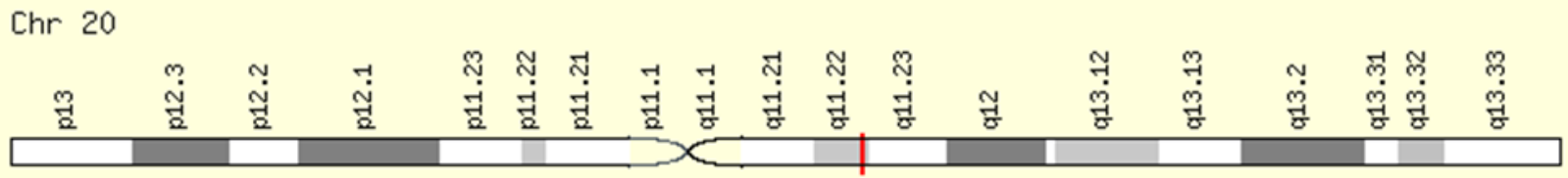

Figure 6. GDF5 gene localization on chromosome 20q11.22 [38].

\section{ELN gene}

The ELN (Elastin) gene is located on chromosome 7q11. 23, Figure 3. The gene encodes the protein elastin, which is one of the two components of elastin fibers. Elastin fibers form part of the extracellular matrix and provide elasticity to organs and tissues, including the heart, skin, lungs, ligaments, and blood vessels [36].

The carriership of SNV rs2289360 of the ELN gene is associated with a predisposition to tendon and ligament injuries in athletes $[16,17,22]$. In addition, SNVs can be located in both the coding and non-coding regions of the gene and affect the athlete's response to a certain training regime, risk of injury, and recovery period rate [8].

Artells R. et al. (2016) conducted an associative genetic study of the SNV rs2289360 of the ELN gene in professional athletes divided into 2 comparison groups, depending on the presence or absence of a medial collateral tendon injury. Homozygous AA genotype of the ELN gene carriers were predisposed to more serious tendon injuries ( $>50 \%$ of connective tissue damage) and had long recovery periods ( $>80$ days) [1].

Similar data were obtained by a group of researchers Pruna R. et al. (2013), who also found that the homozygous AA genotype of this SNV of ELN gene is associated with a high severity of tendon injuries and a longer recovery period compared to carriers of the AG and GG genotypes [22].

\section{VDR gene}

The VDR (Vitamin D Receptor) gene is localized on chromosome 12q13. 11, Figure 5. The gene encodes the vitamin D3 receptor, the downstream targets of the vitamin D3 receptor are mainly involved in mineral metabolism [37].

Among the few SNVs identified in the VDR gene, only the FokI polymorphism is located in the exon sequence. FokI polymorphism (rs2228570) is a C-T transition polymorphic region located in the VDR starting codon that affects the amino acid sequence and function of the encoded receptor protein [23]. Allelic variants of this polymorphism encode structurally different receptor proteins (from the wild type of amino acid 424 encoded by the $\mathrm{F}$ allele to the long protein of amino acid 427 encoded by the $\mathrm{f}$ allele). 
Table 1. Candidate genes and their SNV associated with sports injuries in cyclic sports athletes

\begin{tabular}{|c|c|c|c|}
\hline Gene & SNV/ polymorphism & Predisposition to sports injury & References \\
\hline \multirow[t]{4}{*}{ COL1A1 } & $\begin{array}{l}\text { rs1107946 } \\
\text { rs1800012 }\end{array}$ & $\begin{array}{l}\text { The G-T haplotype }(-1997 \mathrm{G} / \mathrm{T} \text { rs } 1107946 \text { and }+1245 \mathrm{G} / \mathrm{T} \text { rs1800012) is associated with a } \\
\text { reduced risk of anterior cruciate ligament rupture when two copies are carried }\end{array}$ & [10] \\
\hline & rs1800012 & Not associated with risk of cruciate ligament rupture & [28] \\
\hline & & $\begin{array}{l}t \text { is associated with a reduced risk of sports injuries to tendons and ligaments, } \\
\text { especially cruciate ligament injuries }\end{array}$ & [31] \\
\hline & & A rare homozygous TT genotype may play a protective role & \\
\hline \multirow[t]{7}{*}{ COL5A1 } & BstUI (rs12722) & The homozygous CC BstUI RFLP genotype may play a protective role against anterior & [24] \\
\hline & DpnII [RFLPs] & cruciate ligament ruptures in female athletes & \\
\hline & (rs3196378) & $\begin{array}{l}\text { The association of DpnII RFLP genotypes between the group of athletes with anterior } \\
\text { cruciate ligament rupture and the control one was not established }\end{array}$ & \\
\hline & & The T-allele is a genetic predictor of sports injuries in European athletes & \\
\hline & & Associated with chronic achilles tendinopathy in Australian athletes & [26] \\
\hline & & $\begin{array}{l}\text { Homozygous CC genotype for BstUI RFLP reduces the risk of developing tendinopa- } \\
\text { thy regardless of athletes' ethnicity (Australians, South Africans) }\end{array}$ & \\
\hline & & T-C haplotype increases risk of tendinopathy in South African athletes & \\
\hline \multirow{5}{*}{ MMP3 } & rs679620 & Homozygous GG genotype increases the risk of sports injuries in European athletes & [24] \\
\hline & rs591058 & CC genotype increases the risk of Achilles tendinopathy in athletes & \\
\hline & rs650108 & Homozygous AA genotype increases the risk of Achilles tendinopathy in athletes & \\
\hline & rs3025058 & $\begin{array}{l}\text { Associated with an increased risk of Achilles tendinopathy in the South African group } \\
\text { of athletes }\end{array}$ & [12] \\
\hline & rs3025058 & $\begin{array}{l}\text { Haplotype 6A-GCG is associated with a reduced risk of Achilles tendinopathy in the } \\
\text { Australian group of athletes }\end{array}$ & \\
\hline$E L N$ & rs2289360 & $\begin{array}{l}\text { The homozygous AA genotype is associated with more serious tendon injuries ( }>50 \% \\
\text { connective tissue damage) and longer recovery times ( }>80 \text { days) }\end{array}$ & {$[1,22]$} \\
\hline \multirow[t]{2}{*}{ VDR } & FokI (rs2228570) & $\begin{array}{l}\text { The } \mathrm{F} \text { allele is associated with a 2-fold increased risk of spinal diseases and injuries in } \\
\text { athletes }\end{array}$ & [3] \\
\hline & & The $\mathrm{f}$ allele is associated with a reduced risk of spinal diseases and injuries in athletes & [19] \\
\hline \multirow[t]{2}{*}{ GDF5 } & rs143383 & $\begin{array}{l}\text { The A allele is associated with a decrease in the transcriptional activity of the GDF5 } \\
\text { gene in chondrocytes }\end{array}$ & [27] \\
\hline & & $\begin{array}{l}\text { The homozygous GG genotype is associated with increased transcriptional activity of } \\
\text { the GDF5 gene in chondrocytes }\end{array}$ & \\
\hline
\end{tabular}

Short and long protein variants are associated with different functional efficiency of the protein. The binding of VDR to transcription factor II B (TFIIB) determines the different ability to induce transcription of $V D R$-dependent genes (vitamin $D$ response elements, VDREs) [5]. The shorter wild protein (corresponding to the $\mathrm{F}$ allele) appears to interact more effectively with TFIIB, demonstrating a higher transcription rate [15]. Therefore, studies concerning the possible association of VDR-FokI polymorphism with diseases of the musculoskeletal system in athletes may be interesting from the point of view of potential biological significance. $V D R$-FokI is an independent polymorphic site, unrelated to other VDR-SNVs [29]. The distribution of genotypes and alleles of the VDR - FokI polymorphism may vary depending on the genetic background. Therefore, research focused on specific ethnic groups is needed [6].

The musculoskeletal system is a highly adaptable system, responding to external stimuli. Physical exercise, especially high-intensive one, is one of the important factors that can lead to a significant improvement in bone homeostasis in general. Bone tissue can adapt to external stress by changing its microstructure, mass, and size so as to maintain internal effective strain levels within a physiologically reasonable and safe range in athletes. Studies have shown that the homozygous FF genotype may be associated with the formation of a stronger bone structure during intensive training in athletes than the heterozygous Ff genotype.

\section{GDF5 gene}

The GDF5 (Growth Differentiation Factor 5) gene is localized on chromosome 20q11. 22 , Figure 7 . The gene encodes growth differentiation factor 5 , which is a secreted ligand 
of the TGF-beta protein superfamily (transforming growth factor-beta). This protein regulates the development of many types of tissues and cells, including cartilage, joints, brown fat, teeth, as well as neuronal axons and dendrites growth [38].

Physical performance and risk of sports injuries are associated with ligaments and tendons properties, which depend on athletes' individual genotypes. In a study by Stastny P. et al. (2019) it was shown that carriers of the A SNV allele in rs143383 of the GDF5 gene had lower transcriptional activity of the GDF5 gene in chondrocytes than homozygous GG carriers [27]. It may affect the vertebral cartilage size, the limbs size, or the joints angles [25]. The authors investigated the association of SNV rs143383 of the GDF5 gene with the performance of a test to assess the functional and mechanical properties of the lower extremities and obtained the following results. Carriers of the homozygous GG genotype had the best test results regardless of the athlete's gender. It can be assumed that homozygous carriers of rs143383 GG will demonstrate a good level of functional and mechanical properties development of the lower extremities joints which could protect them from potential sports injury [27].

\section{Discussion}

The generalized results of the review are presented in Table 1 . The analyzed studies have shown that SNVs rs1800012, rs1107946 of the COL1A1 gene, SNV rs12722 of the COL5A1 gene, SNV rs679620 of the MMP3 gene, SNV rs2289360 of the ELN gene, SNV rs143383 of the GDF5 gene are associated with injuries of muscles and tendons in cyclic sports athletes. The most studied polymorphisms are rs1800012, rs1107946 of the COL1A1 gene, rs12722 of the COL5A1 gene, and rs143383 of the GDF5 gene.

The variable results of the analyzed associative genetic studies are most likely due to the racial and ethnic heterogeneity of the samples and the differences in the study design.

\section{Conclusions}

The identification of genetic markers associated with diseases of the musculoskeletal system, ligamentous apparatus, and the ability of tissue to regenerate in athletes can help sports doctors and coaches develop personalized strategies to prevent or reduce diseases of the muscles, joints, and ligaments, thus reducing the risk of professional maladjustment and anxiety-depressive disorders in athletes at local and international levels.

Translating the results of studies of candidate genes associated with muscle and tendon injuries into the training process is important for improving cyclic sports athletes' performance.

Author Contributions: B.O.V.: writing original draft preparation, review and editing, supervision, project administration. I have read and agreed to the published version of the manuscript

Funding: This research received no external funding

Institutional Review Board Statement: the study did not involve humans or animals.

Informed Consent Statement: the study did not involve humans.

Data Availability Statement: I would like to express my gratitude to Natalia A. Schneider, Doctor of Medical Sciences, Professor, for her inspiration and assistance in the preparation, technical editing and publication of this article

Conflicts of Interest: I declare that there is no conflict of interest. 


\section{References}

1. Artells, R., Pruna, R., Dellal, A., Maffulli, N. Elastin: a possible genetic biomarker for more severe ligament injuries in elite soccer. A pilot study. Muscles Ligaments Tendons J 2016, 6(2), 188-192. doi: 10.11138/mltj/2016.6.2.188. PMID: 27900291; PMCID: PMC5115249.

2. Bikle, D.D. Vitamin D, metabolism, mechanism of action, and clinical applications. Chem Biol 2014, 21(3), 319-329. doi: 10.1016/j.chembiol.2013.12.016.

3. Cauci, S., Migliozzi, F., Trombetta, C.S., Venuto, I., Saccheri, P., Travan, L., Chiriacò, G. Low back pain and FokI (rs2228570) polymorphism of vitamin D receptor in athletes. BMC Sports Sci Med Rehabil 2017, 9, 4. doi: 10.1186/s13102-017-0069-x. PMID: 28184307; PMCID: PMC5294822.

4. Collins, M., Raleigh, S.M. Genetic risk factors for musculoskeletal soft tissue injuries. Med Sport Sci 2009, 54, 136-49. DOI: 10.1159 / 000235701.

5. Colombini, A., Brayda-Bruno, M., Lombardi, G., Croiset, S.J., Ceriani, C., Buligan, C., Barbina, M., Banfi, G., Cauci, S. BsmI, ApaI and TaqI Polymorphisms in the Vitamin D Receptor Gene (VDR) and Association with Lumbar Spine Pathologies: An Italian Case-Control Study. PLoS One 2016, 11(5), e0155004. doi: 10.1371/journal.pone.0155004. PMID: 27149110; PMCID: PMC4858196.

6. Colombini, A., Cauci, S., Lombardi, G., Lanteri, P., Croiset, S., Brayda-Bruno, M., Banfi, G. Relationship between vitamin D receptor gene (VDR) polymorphisms, vitamin D status, osteoarthritis and intervertebral disc degeneration. J Steroid Biochem Mol Biol 2013, 138, 24-40. doi: 10.1016/j.jsbmb.2013.03.001. PMID: 23500379.

7. Colombini, A., Lanteri, P., Lombardi, G., Grasso, D., Recordati, C., Lovi, A., Banfi, G., Bassani, R., Brayda-Bruno, M. Metabolic effects of vitamin D active metabolites in monolayer and micromass cultures of nucleus pulposus and annulus fibrosus cells isolated from human intervertebral disc. Int J Biochem Cell Biol 2012, 44(6), 1019-30. doi: 10.1016/j.biocel.2012.03.012. PMID: 22481027.

8. Colomer, R., Monzo, M., Tusquets, I., Rifa, J., Baena, J.M., Barnadas, A., Calvo, L., Carabantes, F., Crespo, C., Muñoz, M., Llombart, A., Plazaola, A., Artells, R., Gilabert, M., Lloveras, B., Alba. E. A single-nucleotide polymorphism in the aromatase gene is associated with the efficacy of the aromatase inhibitor letrozole in advanced breast carcinoma. Clin Cancer Res 2008, 14(3), 811-6. doi: 10.1158/1078-0432.CCR-07-1923. PMID: 18245543.

9. Dahlquist, D.T., Dieter, B.P., Koehle, M.S. Plausible ergogenic effects of vitamin D on athletic performance and recovery. J Int Soc Sports Nutr 2015, 12(1), 33 doi: 10.1186/s12970-015-0093-8.

10. Ficek, K., Cieszczyk, P., Kaczmarczyk, M., Maciejewska-Karłowska, A., Sawczuk, M., Cholewinski, J., Leonska-Duniec, A., Stepien-Slodkowska, M., Zarebska, A., Stepto, N.K., Bishop, D.J., Eynon, N. Gene variants within the COL1A1 gene are associated with reduced anterior cruciate ligament injury in professional soccer players. J Sci Med Sport 2013, 16(5), 396400. doi: 10.1016/j.jsams.2012.10.004. PMID: 23168334.

11. Frank, C.B. Ligament structure, physiology and function. J Musculoskelet Neuronal Interact 2004, 4(2), 199-201. PMID: 15615126.

12. Gibbon, A., Hobbs, H., van der Merwe, W., Raleigh, S.M., Cook, J., Handley, C.J., Posthumus, M., Collins. M., September. A.V. The MMP3 gene in musculoskeletal soft tissue injury risk profiling: A study in two independent sample groups. $J$ Sports Sci. 2017, 35(7), 655-662. doi: 10.1080/02640414.2016.1183806. PMID: 27211292.

13. Haussler, M.R., Whitfield, G.K., Kaneko, I., Haussler, C.A., Hsieh, D., Hsieh, J.C., Jurutka, P.W. Molecular mechanisms of vitamin D action. Calcif Tissue Int 2013, 92(2), 77-98. doi: 10.1007/s00223-012-9619-0. PMID: 22782502.

14. Hoffmann, A., Gross, G. Tendon and ligament engineering in the adult organism: mesenchymal stem cells and gene-therapeutic approaches. International orthopaedics 2007, 31, 791-797. doi: 10.1007 / s00264-007-0395-9.

15. Jurutka, P.W., Remus, L.S., Whitfield, G.K., Thompson, P.D., Hsieh, J.C., Zitzer, H., Tavakkoli, P., Galligan, M.A., Dang, H.T., Haussler, C.A., Haussler, M.R. The polymorphic N terminus in human vitamin D receptor isoforms influences transcriptional activity by modulating interaction with transcription factor IIB. Mol Endocrinol 2000, 14(3), 401-20. doi: 10.1210/mend.14.3.0435. PMID: 10707958.

16. Kambouris, M., Ntalouka, F., Ziogas, G., Maffulli, N. Predictive genomics DNA profiling for athletic performance. Recent Pat DNA Gene Seq 2012, 6(3), 229-39. doi: 10.2174/187221512802717321. PMID: 22827597.

17. Longo, U.G., Loppini, M., Margiotti, K., Salvatore, G., Berton, A., Khan, W.S., Maffulli, N., Denaro, V. Unravelling the genetic susceptibility to develop ligament and tendon injuries. Curr Stem Cell Res Ther 2015, 10(1), 56-63. doi: 10.2174/1574888x09666140710112535. PMID: 25012736.

18. Mokone, G.G., Gajjar, M., September, A.V., Schwellnus, M.P., Greenberg, J., Noakes, T.D., Collins, M. The guanine-thymine dinucleotide repeat polymorphism within the tenascin-C gene is associated with achilles tendon injuries. Am J Sports Med 2005, 33(7), 1016-21. doi: 10.1177/0363546504271986. PMID: 15983124.

19. Nakamura, O., Ishii, T., Ando, Y., Amagai, H., Oto, M., Imafuji, T., Tokuyama, K. Potential role of vitamin D receptor gene polymorphism in determining bone phenotype in young male athletes. J Appl Physiol 2002, 93(6), 1973-9. doi: 10.1152/japplphysiol.00663.2002. Epub 2002 Aug 16. PMID: 12391072.

20. Pojednic, R.M., Ceglia, L. The emerging biomolecular role of vitamin D in skeletal muscle. Exerc Sport Sci Rev 2014, 42(2), 76-81. doi: 10.1249/JES.0000000000000013. 
21. Posthumus, M., September, A.V., O’Cuinneagain, D., van der Merwe, W., Schwellnus, M.P., Collins, M. The COL5A1 Gene Is Associated With Increased Risk of Anterior Cruciate Ligament Ruptures in Female Participants. The American Journal of Sports Medicine 2009, 37(11), 2234-2240. doi:10.1177/0363546509338266

22. Pruna, R., Artells, R., Ribas, J., Montoro, B., Cos, F., Muñoz, C., Rodas, G., Maffulli, N. Single nucleotide polymorphisms associated with non-contact soft tissue injuries in elite professional soccer players: influence on degree of injury and recovery time. BMC Musculoskelet Disord 2013, 14, 221. doi: 10.1186/1471-2474-14-221. PMID: 23890452; PMCID: PMC3726514.

23. Puthucheary, Z., Skipworth, J.R., Rawal, J., Loosemore, M., Van Someren, K., Montgomery, H.E. Genetic influences in sport and physical performance. Sports Med 2011, 41(10), 845-59. doi: 10.2165/11593200-000000000-00000. PMID: 21923202.

24. Raleigh, S.M., van der Merwe, L., Ribbans, W.J., Smith, R.K., Schwellnus, M.P., Collins, M. Variants within the MMP3 gene are associated with Achilles tendinopathy: possible interaction with the COL5A1 gene. Br J Sports Med 2009, 43(7), 514-20. doi: 10.1136/bjsm.2008.053892. PMID: 19042922.

25. Sanna, S., Jackson, A.U., Nagaraja, R., Willer, C.J., Chen, W.M., Bonnycastle, L.L., Shen, H., Timpson, N., Lettre, G., Usala, G., Chines, P.S., Stringham, H.M., Scott, L.J., Dei, M., Lai, S., Albai, G., Crisponi, L., Naitza, S., Doheny, K.F., Pugh, E.W., Ben-Shlomo, Y., Ebrahim, S., Lawlor, D.A., Bergman, R.N., Watanabe, R.M., Uda, M., Tuomilehto, J., Coresh, J., Hirschhorn, J.N., Shuldiner, A.R., Schlessinger, D., Collins, F.S., Davey Smith, G., Boerwinkle, E., Cao, A., Boehnke, M., Abecasis, G.R., Mohlke, K.L. Common variants in the GDF5-UQCC region are associated with variation in human height. Nat Genet 2008, 40(2), 198-203. doi: 10.1038/ng.74. PMID: 18193045; PMCID: PMC2914680.

26. September, A.V., Cook, J., Handley, C.J., van der Merwe, L., Schwellnus, M.P., Collins, M. Variants within the COL5A1 gene are associated with Achilles tendinopathy in two populations. Br J Sports Med 2009, 43(5), 357-65. doi: 10.1136/bjsm.2008.048793. PMID: 18443036.

27. Stastny, P., Lehnert, M., De Ste Croix, M., Petr, M., Svoboda, Z., Maixnerova, E., Varekova, R., Botek, M., Petrek, M., Kocourkova, L., Cięszczyk, P. Effect of COL5A1, GDF5, and PPARA Genes on a Movement Screen and Neuromuscular Performance in Adolescent Team Sport Athletes. Journal of Strength and Conditioning Research 2019, 8, 2057-2065. doi: 10.1519/JSC.0000000000003142.

28. Stepien-Slodkowska, M., Ficek, K., Zietek, P., Kaczmarczyk, M., Lubkowska, W., Szark-Eckardt, M., Cieszczyk, P. Is the Combination of COL1A1 Gene Polymorphisms a Marker of Injury Risk? J Sport Rehabil 2017, 26(3), 234-238. doi: 10.1123/jsr.2015-0151. PMID: 27632864.

29. Uitterlinden, A.G., Fang, Y., Van Meurs, J.B., Pols, H.A., Van Leeuwen, J.P. Genetics and biology of vitamin D receptor polymorphisms. Gene 2004, 338(2), 143-56. doi: 10.1016/j.gene.2004.05.014. PMID: 15315818.

30. Wan, L.Y., Zhang, Y.Q., Chen, M.D., Liu, C.B., Wu, J.F. Relationship of structure and function of DNA-binding domain in vitamin D receptor. Molecules 2015, 20(7), 12389-99. doi: 10.3390/molecules200712389. PMID: 26198224; PMCID: PMC6332450.

31. Wang, C., Li, H., Chen, K., Wu, B., Liu, H. Association of polymorphisms rs1800012 in COL1A1 with sports-related tendon and ligament injuries: a meta-analysis. Oncotarget 2017, 8(16), 27627-27634. doi:10.18632/oncotarget.15271.

32. Xie, P., Liu, B., Zhang, L., Chen, R., Yang, B., Dong, J., Rong, L. Association of COL1A1 polymorphisms with osteoporosis: a meta-analysis of clinical studies. Int J Clin Exp Med 2015, 8(9), 14764-81. PMID: 26628959; PMCID: PMC4658848.

33. GeneCards The human gene database. Available online: https://www.genecards.org/cgibin/carddisp.pl?gene=COL1A1\&keywords=COL1A1 (accessed on 17 April 2021)

34. GeneCards The human gene database. Available online: https://www.genecards.org/cgibin/carddisp.pl?gene=COL5A2\&keywords=COL5A1 (accessed on 17 April 2021)

35. GeneCards The human gene database. Available online: https://www.genecards.org/cgibin/carddisp.pl?gene=MMP3\&keywords=MMP3 (accessed on 17 April 2021)

36. GeneCards The human gene database. Available online: https://www.genecards.org/cgi-bin/carddisp.pl?gene=ELN\&keywords=ELN (accessed on 17 April 2021)

37. GeneCards The human gene database. Available online: https://www.genecards.org/cgi-bin/carddisp.pl?gene=VDR\&keywords=VDR (accessed on 17 April 2021)

38. GeneCards The human gene database. Available online: https://www.genecards.org/cgi-bin/carddisp.pl?gene=GDF5\&keywords=GDF5 (accessed on 17 April 2021) 